\title{
Analisis Hubungan Kondisi Perairan dengan Terumbu Karang di Desa Pemuteran Buleleng Bali
}

\author{
Sabil Al Alif a*, I Wayan Gede Astawa Karang a, Yulianto Suteja ${ }^{\text {a }}$ \\ a Program Studi Ilmu Kelautan, Fakultas Kelautan dan Perikanan, Universitas Udayana, Kampus UNUD Bukit Jimbaran, Bali 80361, Indonesia \\ * Penulis koresponden. Tel.: +62-858-2930-1607 \\ Alamat e-mail: sabil.alalif@yahoo.com
}

Diterima (received): 18 Oktober 2016; disetujui (accepted): 23 Mei 2017; tersedia secara online (available online): 24 Mei 2017

\begin{abstract}
Coral reefs in the village of Pemuteran used for tourism activities. In the process of growth, the coral reef is strongly influenced by the water conditions both physical and chemical factors. This study aims to determine the characteristics of the water based physical and chemical factors, determine the percentage of coral cover, determine the relationship and influence the quality of the waters with coral reefs. Research carried out at Pemuteran Village in Mey 2016. The method used is linear transects and transect quadrant, principal component analysis to determine the effect of water quality parameters and relationships with coral reef. The results of the characteristics of the waters on physical factors, namely temperature $30-31^{\circ} \mathrm{C}$, depth $4-75 \mathrm{~m}$, brightness $13 \mathrm{~m}$, turbidity $1,2-5,4$ NTU, current velocity $0,1-0,4 \mathrm{~m} / \mathrm{s}$, and the substrate of sand. Based on chemical factors, namely salinity $31,25-31,55 \%$, $\mathrm{pH} 6,9-7,5$, DO 5,5 - 6,4 mg/l, BOD 5 0,57 - 0,76 mg/l, TSS 248-504 mg/l, nitrate 0,021 - 0,908 mg/l, and phosphate 0,065-0,95 mg/l. Coral cover percentage point 1 at $50,67 \%$, points 2 at $65 \%$, points 3 at $35 \%$,points 4 at $85,33 \%$ and points 5 at $16,67 \%$. While the point 6 - 10 there are no coral reefs. The main components of water quality that affect to the coral reef are the turbidity and substrate. The results show that the correlation of temperature and nitrate correlated very weakly. $\mathrm{pH}, \mathrm{DO}, \mathrm{BOD}_{5}$ and phosphate correlated enough. Salinity, current, and TSS strongly correlated. Depth, brightness, turbidity and substrate strongly correlate.
\end{abstract}

Keywords: water condition; coral reef; Pemuteran Vilage

\begin{abstract}
Abstrak
Terumbu karang di Desa Pemuteran dimanfaatkan untuk kegiatan pariwisata. Dalam proses pertumbuhannya, terumbu karang sangat dipengaruhi oleh kondisi perairan baik faktor fisika maupun kimia. Penelitian ini bertujuan mengetahui karakteristik perairan berdasarkan faktor fisika dan kimia, mengetahui persentase tutupan terumbu karang, mengetahui hubungan serta pengaruh kualitas perairan dengan terumbu karang. Penelitian dilakukan di Desa Pemuteran pada Mei 2016. Metode yang digunakan dalam pengambilan data terumbu karang adalah transek garis dan transek kuadran, data kualitas perairan diambil secara insitu, analisis komponen utama untuk mengetahui pengaruh dan hubungan parameter kualitas perairan dengan terumbu karang. Hasil karakteristik perairan berdasarkan faktor fisika yaitu suhu $30-31^{\circ} \mathrm{C}$, kedalaman $4-75 \mathrm{~m}$, kecerahan mencapai $13 \mathrm{~m}$, kekeruhan 1,2-5,4 NTU, kecepatan arus $0,1-0,4 \mathrm{~m} / \mathrm{s}$, dan substrat dasar berupa pasir. Berdasarkan faktor kimia yaitu salinitas 31,25-31,55\%o, pH 6,9-7,5, DO 5,5-6,4 mg/l, BOD 5 0,57-0,76 mg/l, TSS 248-504 mg/l, nitrat 0,021- 0,908 mg/l, dan fosfat 0,065$0,95 \mathrm{mg} / \mathrm{l}$. Persentase tutupan terumbu karang titik 1 sebesar 50,67\%, titik 2 sebesar $65 \%$, titik 3 sebesar $35 \%$, titik 4 sebesar 85,33\% dan titik 5 sebesar 16,67\%. Sedangkan titik 6-10 tidak terdapat terumbu karang. Hasil analisis komponen utama kualitas perairan yang mempengaruhi terumbu karang yaitu, kekeruhan, dan substrat. Hasil korelasi menunjukkan bahwa suhu dan nitrat berkorelasi sangat lemah. $\mathrm{pH}$, DO, BOD5, dan fosfat berkorelasi cukup. Salinitas, Kecepatan arus, dan TSS berkorelasi kuat. Kedalaman, kecerahan, kekeruhan dan substrat berkorelasi sangat kuat.
\end{abstract}

Kata Kunci: kondisi perairan; terumbu karang; Desa Pemuteran 


\section{Pendahuluan}

Desa Pemuteran terletak di Kecamatan Gerokgak Kabupaten Buleleng Bali merupakan daerah wisata yang cukup berkembang sebagai kawasan pariwisata. Desa Pemuteran memiliki luas wilayah $30,33 \mathrm{~km}^{2}$ dengan luas perairannya kurang lebih 15 $\mathrm{km}^{2}$. Desa Pemuteran berbatasan dengan Desa Sumberkima di sebelah barat dan selatan, Desa Banyupoh di sebelah timur dan Laut Bali di sebelah utara. Desa Pemuteran dilewati oleh 4 sungai yang hanya mengalir pada musim hujan sedangkan musim kemarau sungai tersebut kering atau disebut sungai intermittent (BPS Kabupaten Buleleng, 2015). Pemuteran memiliki keindahan terumbu karang alami dan beranekaragam ikan yang ada didalamnya (Arifin dkk., 2017). Selain itu Pemuteran juga terkenal dangan kegiatan konservasi terumbu karang yang dilakukan oleh masyarakat dengan menggunakan terknologi biorock yaitu konservasi terumbu karang dengan menggunakan listrik bertegangan rendah (Dunning, 2015). Luas area penutupan terumbu karang di Desa Pemuteran sebesar 700 ha dengan penutupan karang keras di lokasi biorock sebesar $38,50 \%$ sedangkan pada lokasi reef seen sebesar 43,50\% (Twinandia dkk., 2011).

Pemerintah Bali telah memutuskan untuk merancang dan mengembangkan sebuah jejaring Kawasan Konservasi Perairan (KKP) di sekitar Bali yang memberikan prioritas kepada kegiatankegiatan ekonomi yang lestari. Terdapat 25 kawasan prioritas yang dipandang sebagai kandidat terpenting untuk dimasukkan kedalam jejaring Kawasan Konservasi Perairan salah satunya adalah kawasan perairan Desa Pemuteran Kecamatan Gerokgak Kabupaten Buleleng. Kawasan-kawasan tersebut dipilih berdasarkan keanekaragaman ikan karang, kondisi terumbu karang dan status kelentingan dari karang keras dan ikan karang, sampai pada inventarisir keanekaragaman tingkat spesies, sedangkan kondisi lingkungan tidak dilakukan pemantauan (Mustika dkk., 2012). Perubahan kondisi lingkungan akan mempengaruhi kondisi pada terumbu karang disekitarnya (Siringoringo dan Hadi, 2013). Selain itu Buku Data Status Lingkungan Hidup Daerah Provinsi Bali tahun 2010 menampilkan data kondisi lingkungan hidup di perairan laut sekitar Bali. Tetapi perairan sekitar Desa Pemuteran tidak dilakukan pemantauan kondisi lingkungan secara komperhensif (BLH
Provinsi Bali, 2010). Mengingat pentingnya data kondisi perairan untuk pertumbuhan terumbu karang, maka perlu adanya penelitian mengenai analisis hubungan kondisi perairan dengan terumbu karang di perairan Desa Pemuteran. Data kualitas perairan akan ditampilkan dalam bentuk spasial agar memudahkan dalam proses pembahasan dan juga agar kualitas perairan di Desa Pemuteran dapat dilihat secara menyeluruh. Sehingga penelitian ini dapat dijadikan data dasar oleh pihak-pihak terkait untuk melakukan pengelolaan Kawasan Konservasi Perairan.

Tujuan dari penelitian ini, yaitu untuk mengetahui kondisi perairan berdasarkan faktor fisika dan kimia di perairan Desa Pemuteran, untuk mengetahui persentase tutupan terumbu karang di perairan Desa Pemuteran, mengetahui pengaruh kualitas perairan terhadap terumbu karang di Desa Pemuteran, serta untuk mengetahui hubungan setiap parameter kualitas perairan dengan terumbu karang di Desa Pemuteran.

\section{Metode Penelitian}

\subsection{Waktu dan Lokasi Penelitian}

Penelitian dilaksanakan pada bulan Mei 2016 di perairan Desa Pemuteran. Pengambilan sampel penelitian menggunakan metode random sampling dan dilakukan secara insitu pada 10 titik pengambilan data yang dianggap mewakili daerah sekitar terumbu karang. Peta sebaran terumbu karang berdasarkan Pickel dan Siagian. Peta lokasi penelitian dapat dilihat pada Gambar 1 .

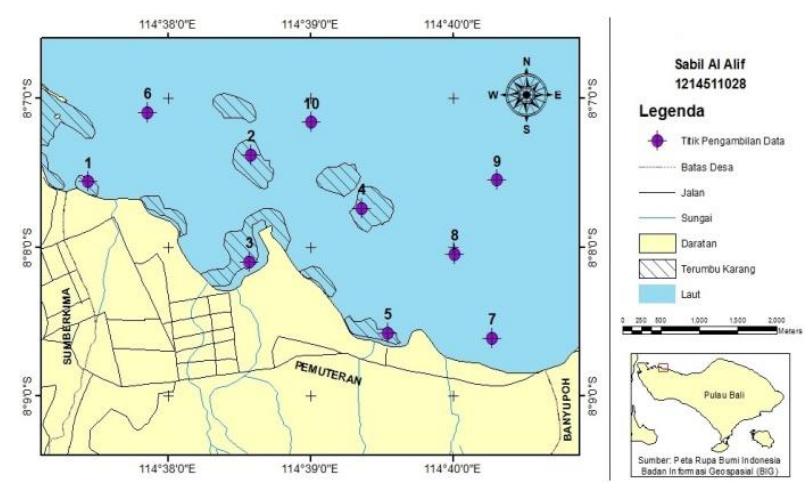

Gambar 1. Lokasi Penelitian

\subsection{Alat dan Bahan}

Alat dan bahan merupakan sarana penunjuang pada pengambilan data ataupun sampel. Adapun 
alat pada penelitian ini ditampilkan pada Tabel 1 dan bahan dari penelitian ini ditampilkan pada Tabel 2.

Tabel 1

Alat yang Digunakan dalam Penelitian

\begin{tabular}{|c|c|c|}
\hline No & Alat & Kegunaan \\
\hline \multirow{2}{*}{1} & \multirow{2}{*}{ CTD } & Mengukur parameter \\
\hline & & kondisi perairan \\
\hline \multirow{2}{*}{2} & \multirow{2}{*}{$\mathrm{pH}$ meter } & Mengukur derajat \\
\hline & & keasaman perairan \\
\hline \multirow{2}{*}{3} & \multirow{2}{*}{ Water sampler } & Untuk mengambil air \\
\hline & & pada kedalaman tertentu \\
\hline \multirow{2}{*}{4} & \multirow{2}{*}{ GPS } & Menentukan lokasi \\
\hline & & pengambilan sampel \\
\hline \multirow{2}{*}{5} & \multirow{2}{*}{ Depth Scan } & Menentukan kedalaman \\
\hline & & perairan \\
\hline \multirow{2}{*}{6} & \multirow{2}{*}{ DO meter } & Menentukan kadar \\
\hline & & oksigen terlarut \\
\hline \multirow{2}{*}{7} & \multirow{2}{*}{ Secchi Disk } & Mengukur kecerahan \\
\hline & & perairan \\
\hline \multirow{2}{*}{8} & \multirow{2}{*}{ Oven } & Mengeringkan kertas \\
\hline & & saring \\
\hline 9 & Timbangan & Menimbang kertas saring \\
\hline 10 & Gelas ukur & Mengukur volume air \\
\hline \multirow{2}{*}{11} & \multirow{2}{*}{ Corong air } & Memudahkan \\
\hline & & penuangan air \\
\hline 12 & Turbidity & Mengukur kekeruhan air \\
\hline \multirow{2}{*}{13} & \multirow{2}{*}{ Cool box } & Menyimpan sampel \\
\hline & & sementara \\
\hline 14 & Perahu & Sarana transportasi \\
\hline 15 & SCUBA diving & Menyelam \\
\hline \multirow{2}{*}{16} & \multirow{2}{*}{ Rol meter } & Pengambilan data \\
\hline & & terumbu karang \\
\hline 17 & Spektrofotometer & Mengukur kadar nitrat \\
\hline 18 & $\begin{array}{l}\text { Lempeng } \\
\text { pemanas }\end{array}$ & Memanaskan larutan \\
\hline 19 & Erlenmeyer & Mengencerkan larutan \\
\hline 20 & Safety goglas & Melindungi mata \\
\hline
\end{tabular}

Pengambilan sampel air dilakukan secara terpadu (integrated sample) dengan mencampur air ditiga kedalaman yang berbeda yaitu permukaan, tengah, dan mendekati dasar untuk mendapatkan nilai sampel yang homogen sehingga dapat mewakili daerah penelitian. Hal ini dikarenakan terumbu karang pada lokasi penelitian hidup diantara kedalaman 3 sampai 20 meter, sehingga sampel air diambil pada tiga kedalaman berbeda dengan asumsi air tersirkulasi. Adapun parameter kualitas air yang diukur adalah suhu, salinitas, $\mathrm{pH}, \mathrm{DO}, \mathrm{BOD}, \mathrm{kedalaman}, \mathrm{kecerahan}, \mathrm{kekeruhan}$, kecepatan arus, TSS, sedimen, nitrat, fosfat dan terumbu karang.

Tabel 2

Bahan yang Digunakan dalam Penelitian

\begin{tabular}{|c|c|c|}
\hline No & Bahan & Kegunaan \\
\hline 1 & Kertas saring & Menyaring air \\
\hline 2 & Botol sampel & Menyimpan sampel air \\
\hline 3 & Kertas label & Memberikan label \\
\hline 4 & Alat tulis & Untuk menulis hasil \\
\hline 5 & Stone ice & Mengawetkan sampel \\
\hline 6 & Sampel air & $\begin{array}{l}\text { Sampel yang akan } \\
\text { diukur }\end{array}$ \\
\hline 7 & $\begin{array}{l}\text { Larutan baku } \\
\text { nitrat }\end{array}$ & $\begin{array}{l}\text { Mengukur kecerahan } \\
\text { perairan }\end{array}$ \\
\hline 8 & Larutan $\mathrm{NaAsO}_{2}$ & Bahan campuran sampel \\
\hline 9 & $\begin{array}{l}\text { Larutan brusin- } \\
\text { asamsulfanilat }\end{array}$ & Bahan campuran sampel \\
\hline 10 & $\begin{array}{l}\text { Larutan asam } \\
\text { sulfat }\end{array}$ & Bahan campuran sampel \\
\hline 11 & $\begin{array}{l}\text { Larutan natrium } \\
\text { klorida }\end{array}$ & Bahan campuran sampel \\
\hline 12 & Air suling & Bahan campuran sampel \\
\hline 13 & Asam nitrat pekat & Bahan campuran sampel \\
\hline 14 & Asam perklorat & Bahan campuran sampel \\
\hline 15 & $\begin{array}{l}\text { Natrium } \\
\text { hidroksida }\end{array}$ & Bahan campuran sampel \\
\hline 16 & $\begin{array}{l}\text { Larutan indikator } \\
\text { jingga metil }\end{array}$ & Bahan campuran sampel \\
\hline 17 & $\begin{array}{l}\text { Larutan indikator } \\
\text { fenolftalein }\end{array}$ & Bahan campuran sampel \\
\hline
\end{tabular}

\subsection{Analisis Data}

\subsubsection{Kondisi Perairan}

Data kondisi perairan yang diperoleh dilakukan perataan dan dianalisis secara diskriptif dan dibandingkan dengan Keputusan Menteri Lingkungan Hidup Nomor 51 Tahun 2004 tentang Baku Mutu Air untuk Biota Laut.

\subsubsection{Analisis Data Terumbu Karang}

Data terumbu karang yang diperoleh, dilakukan analisis persentase tutupan terumbu karang dan dihitung dengan menggunakan persamaan (1).

Persentase tutupan $=\longrightarrow \times 100 \%$ 


\subsubsection{Analisis Komponen Utama}

Analisis komponen utama digunakan untuk menganalisis pengaruh dan hubungan kualitas perairan dengan terumbu karang. Analisis komponen utama bertujuan menyajikan informasi maksimum dalam suatu matriks data kedalam bentuk grafik. Matriks data tersebut terdiri dari stasiun penelitian sebagai individu statistik (matriksbaris) serta parameter kualitas perairan dan terumbu karang sebagai variabel kuantitatif (matriks kolom). Karena data-data tersebut tidak mempunyai unit pengukuran yangsama maka data-data ini dinormalisasikan lebih dahulu melalui pemusatan dan pereduksian. Dengan demikian nilai PCA tidak direalisasikan dari nilainilai parameter inisial, tetapi dari indeks sintetik yang diperoleh dari kombinasi linier nilai-nilai parameter inisial.

\section{Hasil}

\subsection{Faktor Fisika Perairan}

\subsubsection{Suhu}

Hasil pengukuran suhu perairan di Pemuteran Bali menunjukan bahwa nilai suhu bervariasi pada setiap titik pengamatan dan berkisar antara 30 $31^{\circ} \mathrm{C}$. Nilai suhu terendah terdapat pada titik dua yaitu sebesar $30,74^{\circ} \mathrm{C}$, sedangkan nilai suhu tertinggi terdapat pada titik lima yaitu sebesar $31,19^{\circ} \mathrm{C}$. Suhu terendah dan tertinggi di perairan Pemuteran terdapat pada lokasi dimana ada terumbu karang dibawahnya. Sedangkan pada lokasi dimana tidak terdapat terumbu karang nilai suhu berkisar antara 30,81 - 30,98 ${ }^{\circ}$ C. Suhu perairan Desa Pemuteran ditampilkan pada Gambar 2.

\subsubsection{Kedalaman}

Kedalaman perairan di Pemuteran Bali bervariasi pada setiap titik. Kedalaman terendah terdapat pada titik 3 yaitu sedalam $4 \mathrm{~m}$ dan kedalaman tertinggi terdapat pada titik 10 yaitu sedalam $75 \mathrm{~m}$. Kedalaman pada lokasi yang terdapat terumbu karang dibawahnya tidak lebih dari 10 m.Kedalaman terendah terdapat pada titik 3 yaitu sedalam $4 \mathrm{~m}$ dan kedalaman tertinggi terdapat pada titik 4 yaitu sedalam 10 m.Sedangkan pada lokasi yang tidak terdapat terumbu karang dibawahnya, kedalaman tertinggi terletak pada titik 10 yaitu sedalam $75 \mathrm{~m}$ dan kedalaman terendah terletak pada titik 6 yaitu sedalam 17,6 m.Kedalaman perairan Desa Pemuteran ditampilkan pada Gambar 3.

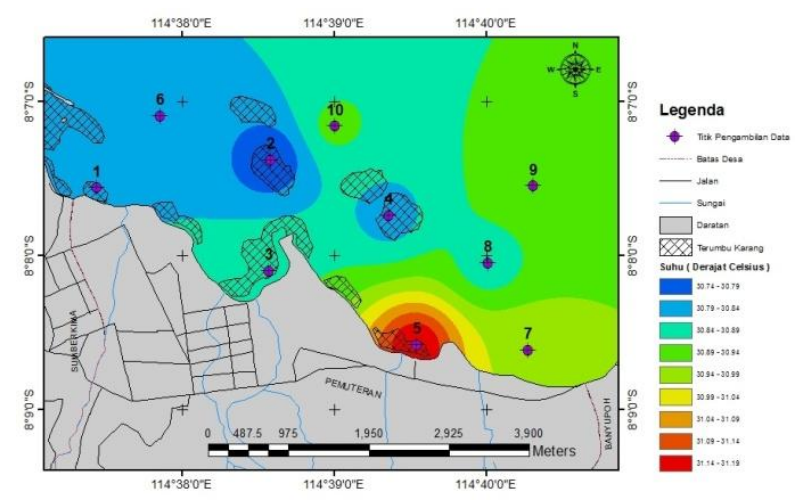

Gambar 2. Suhu perairan di Desa Pemuteran

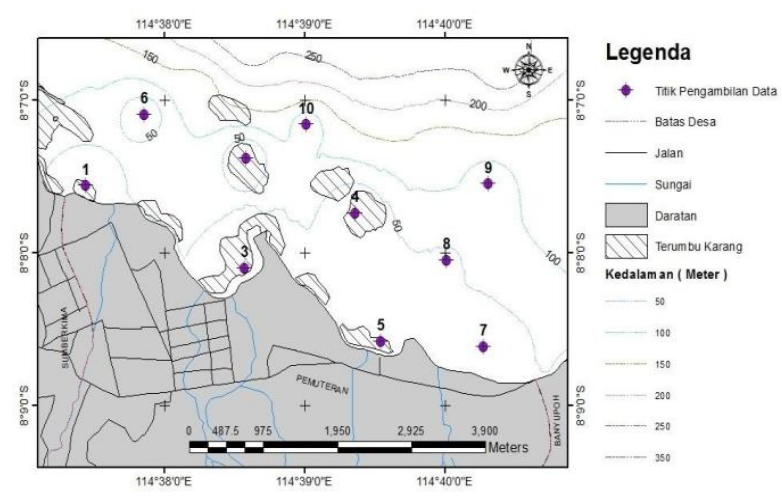

Gambar 3. Kedalaman perairan Desa Pemuteran

\subsubsection{Kecerahan}

Pada titik 1 - 5 dimana terdapat terumbu karang dibawahnya kecerahan sangat baik hingga mencapai dasar perairan. Sedangkan pada titik 6 10 dimana tidak terdapat terumbu karang dibawahnya nilai kecerahan berkisar antara $11-13$ $\mathrm{m}$. Hal ini berarti nilai kecerahan pada perairan Pemuteran Bali dalam kondisi baik. Kecerahan perairan Desa Pemuteran ditampilkan pada Gambar 4.

\subsubsection{Kecepatan Arus}

Nilai kecepatan arus di perairan Pemuteran Bali berkisar antara $0,1-0,4 \mathrm{~m} / \mathrm{s}$. Secara umum pada lokasi yang dekat dengan daratan,kecepatan arusnya lebih rendah dibandingkan dengan lokasi yang jauh dari daratan.Kecepatan arus terendah terdapat pada titik 1, 3, 4, 5, dan 7, dimana lokasi tersebut dekat dengan daratan. 
Sedangkan kecepatan arus tertinggi terdapat pada titik 9 dan 10 yaitu sebesar 0,4 m/s. Kecepatan arus di Desa Pemuteran ditampilkan pada Gambar 5.

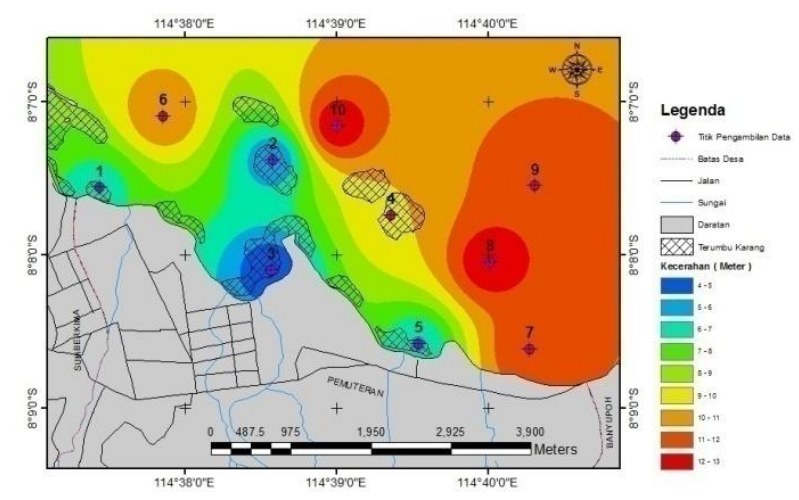

Gambar 4. Kecerahan perairan di Desa Perairan

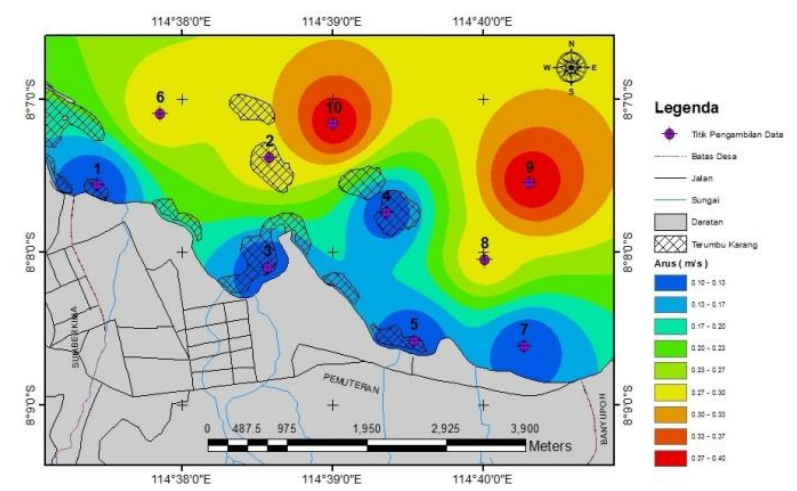

Gambar 5. Kecepatan arus perairan di Desa Pemuteran

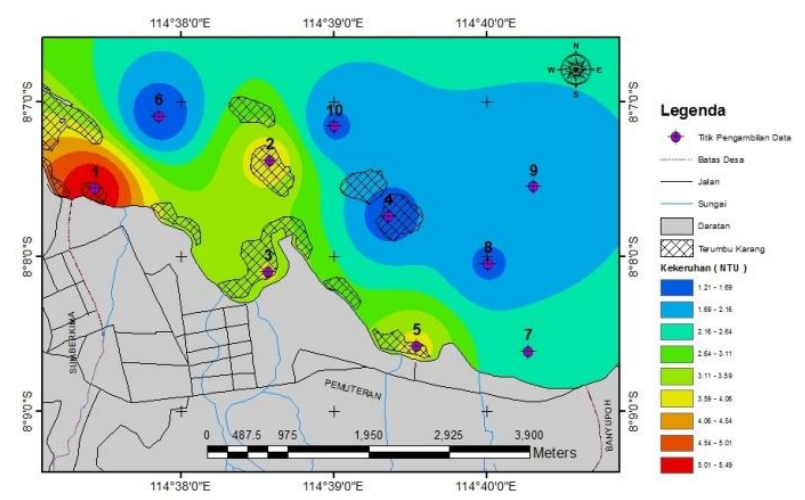

Gambar 6. Kekeruhan perairan di Desa Pemuteran

\subsubsection{Kekeruhan}

Kekeruhan perairan di Pemuteran Bali bervariasi pada setiap titik pengambilan data berkisar antara 1,2 - 5,4 NTU. Kekeruhan tertinggi terdapat pada titik 1 dimana terdapat terumbu karang dibawahnya yaitu sebesar 5,48 NTU. Pada titik ini terdapat keramba jaring apung disekitar lokasi pengambilan sampel sehingga diduga nilai kekeruhan tinggi karena bahan organik dari pakan ikan yang tidak habis dimakan oleh ikan - ikan didalam keramba tersebut dan tersuspensi didalam kolom perairan maupun keberadaan mikroorganisme seperti plankton baik fitoplankton maupun zooplankton yang ada di perairan. Sedangkan kekeruhan terendah terdapat pada titik 6 dimana tidak terdapat terumbu karang dibawahnya yaitu sebesar 1,21 NTU. Kekeruhan perairan Desa Perairan ditampilkan pada Gambar 6.

\subsubsection{Total Suspended Solid (TSS)}

Nilai TSS di perairan Pemuteran Bali berkisar antara $248-504 \mathrm{mg} / \mathrm{l}$. Nilai TSS tertinggi terdapat pada titik 1 yaitu sebesar $504 \mathrm{mg} / \mathrm{l}$ dimana pada titik tersebut nilai kekeruhan juga tinggi. Sedangkan nilai TSS terendah terdapat pada titik 8 yaitu sebesar $248 \mathrm{mg} / \mathrm{l}$ dimana pada titik tersebut tidak terdapat terumbu karang dibawahnya. TSS di Desa Pemuteran ditampilkan pada Gambar 7.

\subsubsection{Substrat Dasar Perairan}

Sampel substrat dasar perairan di Desa Pemuteran yang dapat diambil hanya pada titik $1-6$. Hal ini dikarenakan keterbatasan alat yang digunakan dalam pengambilan substrat dasar dan kondisi kedalaman perairan yang tidak memungkinkan untuk pengambilan sampel. Tipe substrat yang ada di perairan Desa Pemuteran Bali menunjukkan hasil yang seragam. Secara umum tipe substrat berupa pasir dengan persentase rata-rata sebesar 97,79, debu 1,1 \% dan liat 1,1\%. Substrat dasar perairan di Desa Pemuteran ditampilkan dalam Tabel 3

\section{Tabel 3}

Substrat dasar perairan Desa Pemuteran

\begin{tabular}{ccccc}
\hline Titik & $\begin{array}{c}\text { Tipe } \\
\text { Substrat }\end{array}$ & Pasir (\%) & Debu (\%) & Liat (\%) \\
\hline 1 & Pasir & 97,14 & 1,56 & 1,3 \\
2 & Pasir & 96,96 & 1,77 & 1,27 \\
3 & Pasir & 97,72 & 1,01 & 1,27 \\
4 & Pasir & 97,45 & 1,78 & 0,77 \\
5 & Pasir & 98,99 & 0,25 & 0,76 \\
6 & Pasir & 98,48 & 0,25 & 1,27 \\
\hline
\end{tabular}




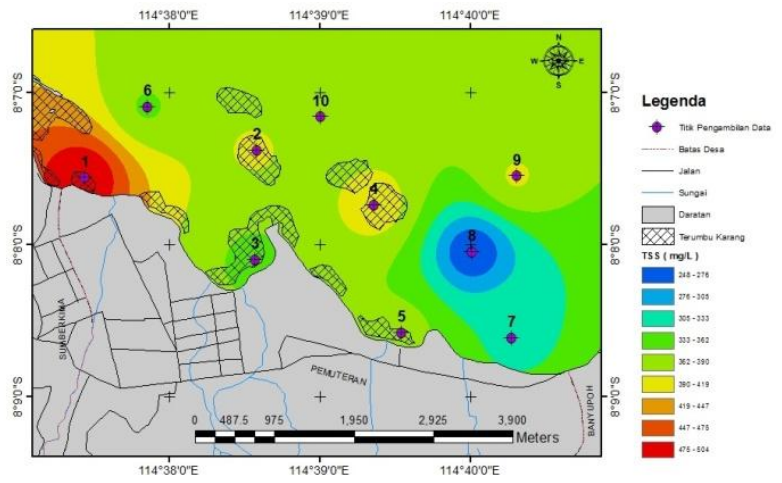

Gambar 7. TSS perairan di Desa Pemuteran

\subsection{Faktor Kimia Perairan}

\subsubsection{Salinitas}

Data salinitas perairan di Pemuteran Bali menunjukan hasil yang cenderung sama di setiap titik pengamatan, baik di lokasi yang terdapat terumbu karang maupun yang tidak terdapat terumbu karang. Rata-rata nilai salinitas berkisar antara 31,25 - 31,55 \%. Salinitas terendah ditemukan pada titik satu dimana terdapat terumbu karang dibawahnya yaitu sebesar $31,25 \%$. Sedangkan salinitas tertinggi ditemukan pada titik empat yaitu sebesar 31,55 \% yang juga merupakan lokasi yang terdapat terumbu karang dibawahnya. Pada lokasi pengamatan yang tidak terdapat terumbu karang dibawahnya, nilai salinitas terendah terdapat pada titik sembilan yaitu sebesar $31,51 \%$. sedangkan nilai salinitas tertinggi terdapat pada titik tujuh yaitu sebesar 31,53 \% . Salinitas perairan di Desa Pemuteran ditampilkan pada Gambar 8.

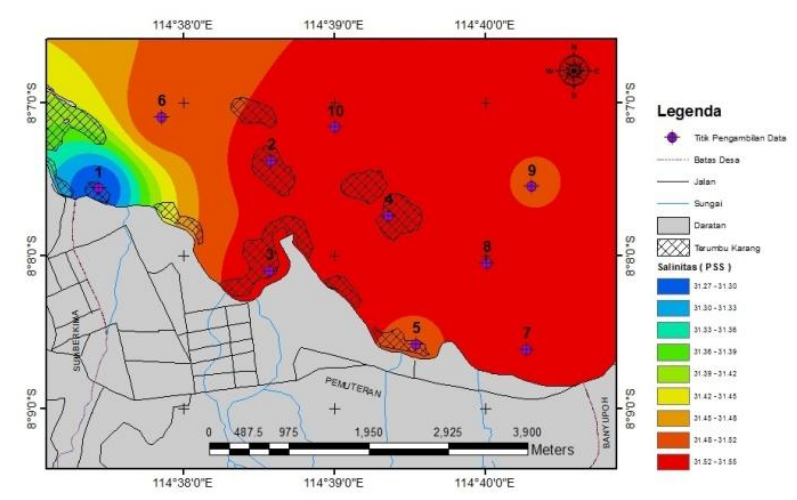

Gambar 8. Salinitas perairan di Desa Pemuteran

\subsubsection{Power of Hydrogen (pH)}

Nilai Power of Hydrogen $(\mathrm{pH})$ di perairan Pemuteran Bali menunjukkan hasil yang bervariasi terutama pada lokasi yang terdapat terumbu karang dibawahnya. Nilai $\mathrm{pH}$ berkisar antara 6,9-7,5 dengan nilai $\mathrm{pH}$ terendah pada titik satu sebesar 6,9 dan tertinggi pada titik tiga yaitu sebesar 7,5. Pada lokasi yang tidak terdapat terumbu karang dibawahnya, nilai $\mathrm{pH}$ cenderung sama di semua lokasi yaitu sebesar 7,2 akan tetapi di titik sepuluh nilai $\mathrm{pH}$ sebesar 7,4. $\mathrm{pH}$ perairan di Desa Pemuteran ditampilkan pada Gambar 9.

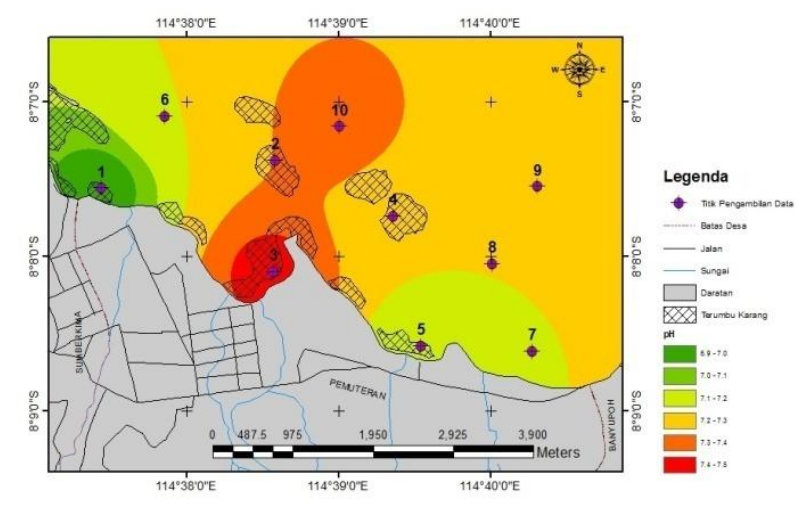

Gambar 9. pH perairan di Desa Pemuteran

\subsubsection{Disolve Oxygen (DO)}

Disolve Oxygen (DO) di perairan Pemuteran Bali menunjukan nilai yang bervariasi. Nilai DO berkisar antara 5,5 - 6,4 mg/l. Dimana nilai DO terendah terdapat pada titik 10 yaitu sebesar 5,54 $\mathrm{mg} / \mathrm{l}$ dan nilai DO tertinggi terdapat pada titik 9 yaitu sebesar $6,41 \mathrm{mg} / \mathrm{l}$. Nilai DO terendah dan tertinggi terdapat pada lokasi yang tidak terdapat terumbu karang dibawahnya. Sedangkan pada lokasi yang terdapat terumbu karang dibawahnya, nilai DO berkisar antara 5,6-6,3 mg/l. Nilai DO terendah terdapat pada titik 1 yaitu sebesar 5,68 dan nilai DO tertinggi terdapat pada titik 4 yaitu sebesar 6,33 mg/l. DO perairan di Desa Pemuteran ditampilkan pada Gambar 10.

\subsubsection{Biological Oxygen Demand (BOD)}

Biological Oxygen Demand (BOD) adalah oksigen yang dibutuhkan untuk proses biologis. BOD erat kaitannya dengan oksigen terlarut (DO) di perairan.Secara umum nilai BOD yang dicari adalah nilai BOD harian.Nilai ini diperoleh dari perata-rataan nilai DO awal dan nilai DO akhir sehingga didapatkan nilai BOD.Nilai BOD5 di perairan Desa Pemuteran Bali berkisar antara 0,57 - 0,76 mg/l. Nilai BOD5 terendah terdapat pada titik 5 yaitu sebesar $0.57 \mathrm{mg} / \mathrm{l}$ dimana pada titik tersebut terdapat terumbu karang dibawahnya. 
Sedangkan nilai BOD5 tertinggi terdapat pada titik 4 yaitu sebesar $0.76 \mathrm{mg} / \mathrm{l}$ dimana pada titik tersebut juga terdapat terumbu karang dibawahnya. BOD perairan di Desa Pemuteran ditampilkan pada Gambar 11.

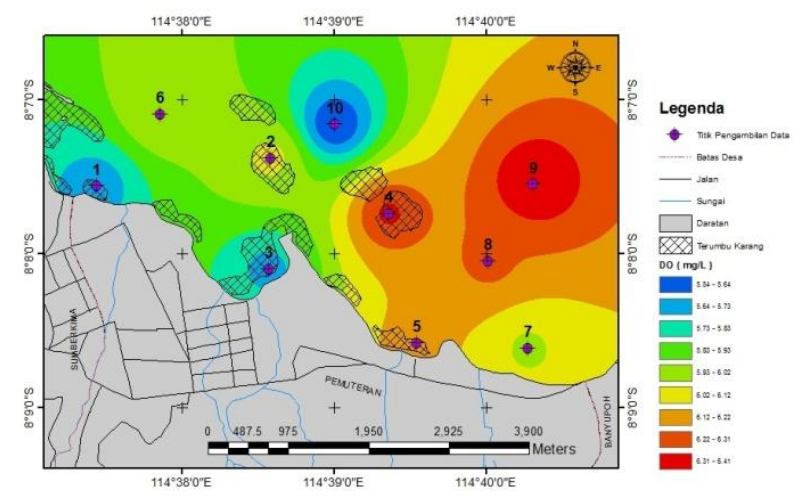

Gambar 10. DO perairan di Desa Pemuteran

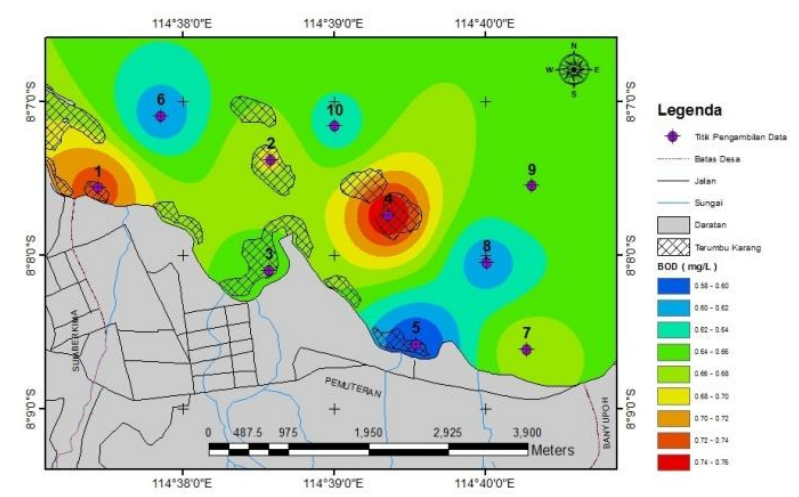

Gambar 11. BOD perairan di Desa Pemuteran

\subsubsection{Nitrat}

Nitrat di perairan Desa Pemuteran Bali sangat bervariasi pada setiap titik pengambilan data. Nilai rata-rata nitrat di perairan Pemuteran Bali yaitu sebesar $0,414 \mathrm{mg} / \mathrm{l}$. Nilai nitrat tertinggi terdapat pada titik 1 yaitu sebesar $0,908 \mathrm{mg} / \mathrm{l}$ dimana pada titik tersebut terdapat terumbu karang dibawahnya dan terdapat keramba jarring apung disekitarnya. Sedangkan nilai nitrat terendah terdapat pada titik 5 yaitu sebesar 0,021 $\mathrm{mg} / \mathrm{l}$ dimana juga terdapat terumbu karang dibawahnya. Nitrat perairan di Desa Pemuteran ditampilkan pada Gambar 12.

\subsubsection{Fosfat}

Nilai fosfat di perairan Pemuteran Bali sangat bervariasi pada setiap titik pengambilan data.. Nilai rata-rata fosfat di perairan Pemuteran Bali yaitu sebesar $0,074 \mathrm{mg} / \mathrm{l}$. Nilai fosfat tertinggi terdapat pada titik 3 yaitu sebesar $0,95 \mathrm{mg} / \mathrm{l}$ dimana pada titik tersebut terdapat terumbu karang dibawahnya. Sedangkan nilai fosfat terendah terdapat pada titik 10 yaitu sebesar 0,065 $\mathrm{mg} / \mathrm{l}$ dimana pada titik tersebut tidak terdapat terumbu karang dibawahnya. Fosfat perairan di Desa Pemuteran ditampilkan pada Gambar 13.

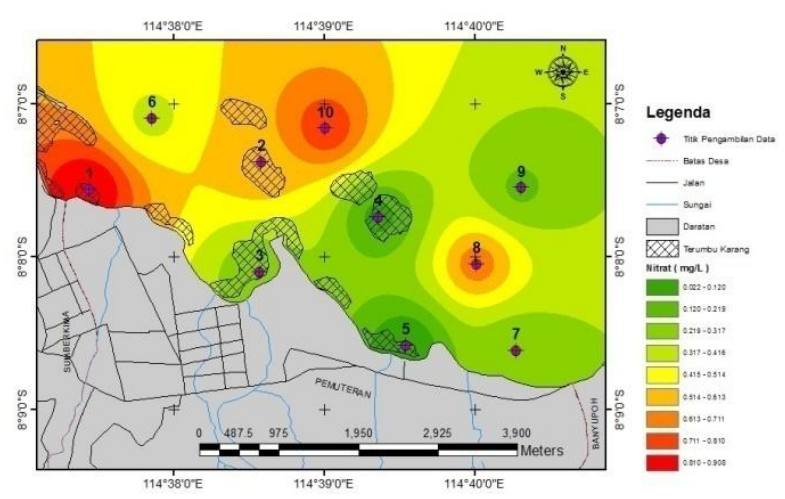

Gambar 12. Nitrat perairan di Desa Pemuteran

\subsection{Persentase Tutupan Terumbu Karang}

Persentase tutupan terumbu karang hidup di Pemuteran Bali bervariasi pada setiap titik. Persentase tutupan terumbu karang hidup tertinggi terdapat pada titik 4 dan terendah terdapat pada titik 5. Pada titik 1 persentase tutupan terumbu karang hidup yaitu sebesar $50,67 \%$. Pada titik 2 persentase tutupan karang hidup yaitu sebesar $65 \%$. Pada titik 3 persentase tutupan karang hidup yaitu sebesar $35 \%$. Pada titik 4 persentase tutupan karang hidup yaitu sebesar $85,33 \%$. Pada titik 5 persentase tutupan karang hidup yaitu sebesar 16,67\%. Persentase tutupan terumbu karang ditampilkan pada Gambar 14.

\subsection{Analisis Komponen Utama}

Hasil analisis komponen utama memperlihatkan bahwa informasi penting terhadap sumbu terpusat pada 2 sumbu utama yaitu Factor 1 dan Factor 2 dengan kontribusi masing-masing 37,61\% dan $19,74 \%$ dari ragam total $57,25 \%$. Factor 1 dicirikan oleh parameter terumbu karang, substrat, fosfat, kekeruhan, TSS, BOD5, pH, salinitas, kecerahan, kedalaman dan kecepatan arus. Sedangkan factor 2 dicirikan oleh suhu, DO dan nitrat.Hasil tersebut juga menunjukkan bahwa parameter kualitas perairan yang lebih mempengaruhi terumbu karang adalah parameter yang memiliki kedekatan 
sudut dengan terumbu karang yaitu kekeruhan dan substrat.Parameter yang mempengaruhi terumbu karang ditampilkan pada Gambar 15.

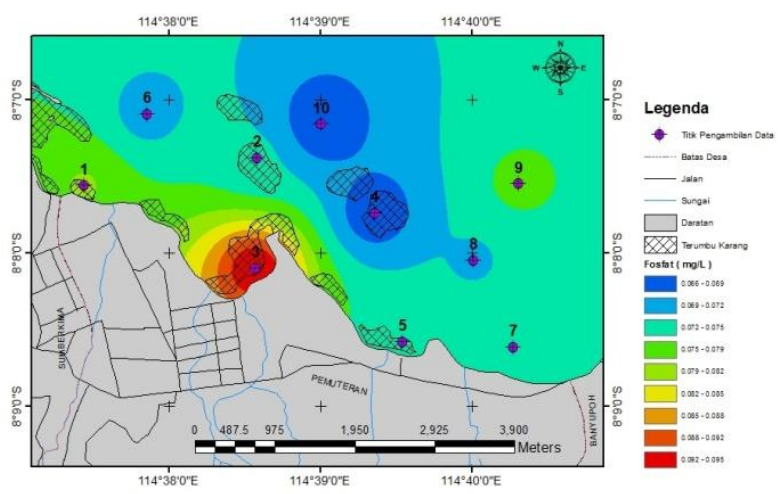

Gambar 13. Fosfat perairan di Desa Pemuteran

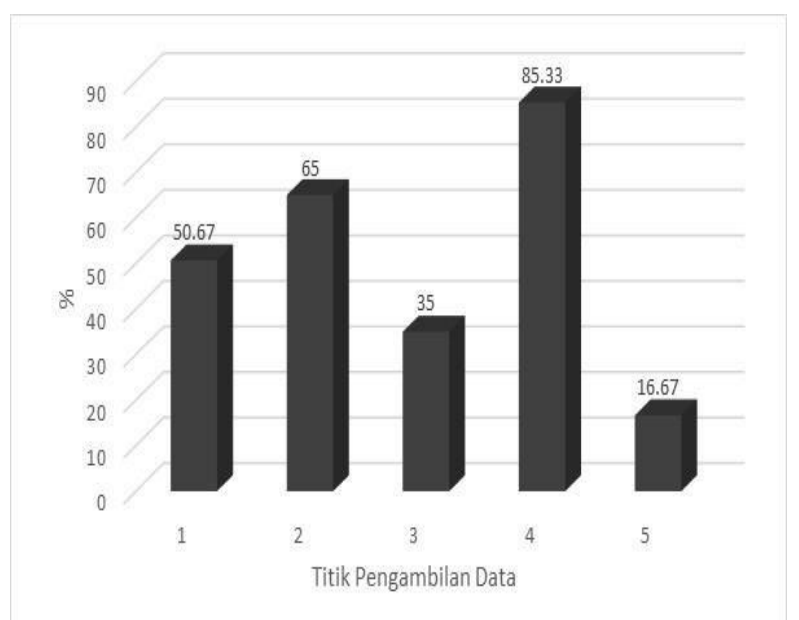

Gambar 14. Persentase tutupan terumbu karang hidup perairan di Desa Pemuteran

\subsection{Korelasi Parameter Kualitas Perairan dengan Terumbu Karang}

Hasil analisis korelasi menunjukkan bahwa suhu $(0,066)$ perairan dan nitrat $(-0,065)$ berkorelasi sangat lemah terhadap terumbu karang. Parameter kualitas perairan yang berkorelasi cukup terhadap terumbu karang yaitu $\mathrm{pH}(0,403)$, DO $(0,323)$, BOD5 $(-0,471)$, dan fosfat $(-0,482)$. Korelasi kuat terjadi antara parameter kualitas air seperti salinitas $(0,671)$, kecepatan arus $(0,707)$, dan TSS $(-0,724)$ dengan terumbu karang. Sedangkan yang memiliki korelasi sangat kuat terhadap terumbu karang di perairan Desa Pemuteran adalah kedalaman $(0,792)$, kecerahan $(0,830)$, kekeruhan $(-0,866)$ dan substrat $(-0,776)$. Korelasi parameter kualitas perairan dengan terumbu karang ditampilkan dalam Tabel 4.

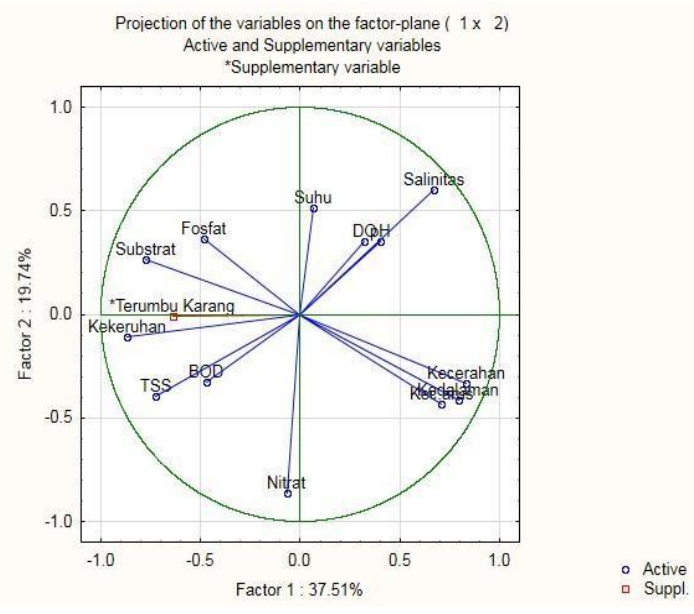

Gambar 15. Grafik parameter yang mempengaruhi terumbu karang di Desa Pemuteran

\section{Tabel 4}

Korelasi parameter kualitas perairan dengan Terumbu Karang

\begin{tabular}{clc}
\hline No & \multicolumn{1}{c}{$\begin{array}{c}\text { Parameter Kualitas } \\
\text { Perairan }\end{array}$} & Korelasi \\
\hline 1 & Suhu & 0,066 \\
2 & Salinitas & 0,671 \\
3 & pH & 0,403 \\
4 & DO & 0,323 \\
5 & Kedalaman & 0,792 \\
6 & Kecerahan & 0,830 \\
7 & Kekeruhan & $-0,866$ \\
8 & Kecepatan arus & 0,707 \\
9 & BOD5 & $-0,471$ \\
10 & TSS & $-0,724$ \\
11 & Nitrat & $-0,065$ \\
12 & Fosfat & $-0,482$ \\
13 & Substrat & $-0,776$ \\
\hline
\end{tabular}

\section{Pembahasan}

Kualitas perairan Desa Pemuteran secara umum masih dalam kondisi baik berdasarkan Keputusan Menteri Lingkungan Hidup Nomor 51 (2004) tentang Baku Mutu Air untuk Biota Laut. Akan tetapi beberapa parameter kualitas perairan tidak sesuai bagi pertumbuhan terumbu karang. Parameter tersebut adalah suhu, salinitas, nitrat dan fosfat. Suhu perairan Desa Pemuteran lebih dari $31^{\circ} \mathrm{C}$. Perubahan suhu secara mendadak dapat menyebabkan karang mengalami stress dan mengeluarkan lendir yang juga dapat menyebabkan karang mati (Ardiansyah dkk., 2013). 
Kondisi nitrat perairan Desa Pemuteran telah jauh melebihi batas baku mutu yaitu sebesar $0,908 \mathrm{mg} / \mathrm{l}$. Fosfat perairan Desa Pemuteran juga telah jauh melebihi baku mutu yaitu sebesar $0,074 \mathrm{mg} / \mathrm{l}$. Nitrat dan fosfat merupahan bahan organik yang dimanfaatkan oleh organisme laut. Akan tetapi keberadaannya juga harus dijaga (Hamzah dkk., 2015). Kelebihan nitrat dapat berdampak buruk bagi lingkungan. Contoh dari kelebihan nitrat yaitu blomming alge (Yolanda dkk., 2016). Bahan organik berasal dari berbagai sumber seperti kegiatan pertambakan, pertanian, pemukiman, industri, pertambangan, pela-buhan dan aktifitas manusia yang akanmasuk melalui aliran sungai atau run-off yang berasal dari daratan (Rokhim dkk., 2009). Tingginya beberapa parameter kualitas perairan berpengaruh terhadap terumbu karang di Desa Pemuteran.

Pada titik 1 tutupan terumbu karang hidup sebesar $50,67 \%$ dan sebesar $49,33 \%$ merupakan tutupan terumbu karang mati, alga dan komponen abiotik. Terumbu karang mati atau dead coral memiliki persentase tutupan yang besar pula yaitu sebesar $18,19 \%$, alga sebesar $15,21 \%$, komponen abiotik sebesar 9,71\% dan fauna lain sebesar 6,22\%. Besarnya persentase terumbu karang yang mati pada titik 1 diduga karena tingginya nilai TSS dan juga kekeruhan melebihi ambang batas baku mutu pada lokasi tersebut. Sehingga mengakibatkan tertutupnya polip dari terumbu karang dan menghambat proses metabolisme. Selain itu rendahnya sirkulasi arus di perairan Pemuteran dibandingkan dengan perairan sekitar Nusa Penida juga mengakibatkan proses transport sedimen semakin lambat dan sedimen akan mengendap. Menurut Putra dkk. (2015), kecepatan arus di perairan sekitar Nusa Penida mencapai $1.08 \mathrm{~m} / \mathrm{s}$. Meningkatnya suhu perairan secara umum akibat dari terjadinya El Nino juga menjadi faktor penyebab matinya terumbu karang (Eghbert et al., 2017; DeCarlo et al., 2017). Terlihat dari beberapa jenis terumbu karang yang memutih dan kemudian ditumbuhi oleh alga pada lokasi tersebut. Hal ini terjadi hampir di semua titik pengamatan di Desa Pemuteran.

Pada titik 2 yang terletak lebih jauh dari garis pantai, persentase tutupan terumbu karang hidup lebih besar dibandingkan dengan titik 1 . Persentase tutupan terumbu karang hidup sebesar $65 \%$, terumbu karang mati $15,71 \%$, alga sebesar $10,21 \%$, komponen abiotik $5,11 \%$ dan fauna lain sebesar 3,97\%. Pada lokasi ini terlihat beberapa jenis terumbu karang telah mengalami pemutihan. Hal ini diduga akibat dari meningkatnya suhu perairan dan tingginya nutrien berupa nitrat dan fosfat yang terdapat pada lokasi penelitian secara keseluruhan. Nilai parameter lingkungan yaitu suhu dan nutrien tidak sesuai bagi pertumbuhan terumbu karang sehingga menyebabkan memutihnya terumbu karang dan matinya terumbu karang (Salim, 2012).

Pada titik 3 lokasi pengamatan dekat dengan garis pantai dan juga terdapat run of dari sungai. Diduga hal tersebut yang mengakibatkan rendahnya persentase tutupan terumbu karang hidup yaitu hanya sebesar 35\%. Sedangkan persentase terumbu karang mati lebih besar yaitu sebesar $35,93 \%$, alga sebesar $20,07 \%$, komponen abiotik $4,71 \%$ dan fauna lain $4,29 \%$. Pada lokasi ini ditemukan banyak terumbu karang yang mati akibat tertutupi lumpur dan juga ditimbuhi alga.

Rendahnya arus pada lokasi ini diduga yang mengakibatkan banyaknya terumbu karang yang mati. Faktor arus dapat berdampak baik atau buruk, bersifat positif apabila membawa nutrien dan bahan-bahan organik yang diperlukan oleh karang dan zooxanthellae, sedangkan bersifat negatif apabila menyebabkan sedimentasi di perairan terumbu karang dan menutupi permukaan karang sehingga berakibat pada kematian karang. Arus diperlukan dalam, proses pertumbuhan karang dalam hal menyuplai makanan berupa mikroplankton (As-Syakur dan Wiyanto, 2016). Tingginya nilai nitrat pada lokasi ini diduga karena adanya keramba jaring apung di sekitar lokasi. Nitrat yang tinggi akan mempercepat proses pertumbuhan dari alga (Ulqodry dkk., 2010). Sehingga menekan pertumbuhan terumbu karang karena persaingan dalam mendapatkan lokasi yang sesuai untuk tumbuh.

Pada titik 4 persentase tutupan terumbu karang hidup sangat besar dan dikategorikan sangat baik. Persentase terumbu katang hidup sebesar 85,33\% dan didominasi oleh massive coral. Terumbu karang pada lokasi ini berbentuk seperti bongkahan batu yang ditumbuhi berbagai macam jenis koloni terumbu karang. Letaknya yang jauh dari garis pantai mengakibatkan pengaruh dari daratan seperti run of sungai tidak berpengaruh secara signifikan bagi kelangsungan hidup terumbu karang (Insafitri, 2010). Persentase terumbu karang yang mati pun lebih rendah dibandingkan dengan lokasi lain yaitu sebesar 
9,71\%, alga sebesar 2,10\%, komponen abiotik sebesar $0,89 \%$ dan fauna lain sebesar 1,97\%.

Pada titik 5 persentase tutupan terumbu karang sangat rendah bahkan termasuk dalam kategori rusak. Terumbu karang yang masih hidup pada lokasi ini hanya sebesar 16,67\%, terumbu karang mati sebesar 53,91\%, alga sebesar 9,53\%, komponen abiotik sebesar $15,41 \%$ dan fauna lain sebesar 4,48\%. Rusaknya terumbu karang pada lokasi ini diduga selain dari faktor kualitas air, akibat adanya tekanan dari daratan berupa run off sungai dan tingginya aktivitas manusia. Lokasi di sekitar terumbu karang merupakan lokasi wisata dan juga tempat parkirnya kapal - kapal. Ramadhani dkk. (2015) mengatakan bahwa secara umum terjadinya degradasi terumbu karang ditimbulkan oleh dua penyebab utama, yaitu akibat kegiatan manusia (anthrophogenic causes) dan akibat alam (natural causes). Pada saat penelitian ini dilakukan, kedua penyebab degradasi terumbu karang sedang terjadi utamanya adalah akibat yang ditimbulkan dari alam yaitu fenomena el nino.

Pada titik 6 sampai dengan 10 tidak ditemukan adanya terumbu karang. Titik 6 dan 7 yang berada pada kedalaman 17 - 20 meter tidak terdapat terumbu karang dibawahnya. Sedangkan titik 8 sampai 10 tidak memungkinkan untuk dilakukan pengamatan terumbu karang karena kedalamannya mencapai 75 meter. Akan tetapi dapat dipastikan tidak terdapat terumbu karang dibawahnya karena menurut Rini dkk. (2015), kebanyakan terumbu karang tumbuh pada kedalaman $25 \mathrm{~m}$ atau kurang. Terumbu karang tidak dapat berkembang di perairan yang lebih dalam dari 50 - $70 \mathrm{~m}$ dan didukung oleh keterangan masyarakat sekitar lokasi penelitian.

Hasil dari analisis analisis komponen utama menunjukkan bahwa terumbu karang di Desa Pemuteran sangat dipengaruhi oleh kekeruhan dan kondisi substrat dasar perairan sehingga terumbu karang tidak dapat menyebar lebih luas. Kekeruhan perairan mempengaruhi proses pertumbuhan dan juga dapat mengakibatkan matinya terumbu karang. Partikel - partikel yang ada dikolom perairan secara perlahan akan mengendap dan menutup polip karang sehingga karang tidak dapat berkembang. Semakin tinggi nilai kekeruhan maka semakin banyak terumbu karang yang mati (Tamam dkk., 2013). Tingginya nilai kekeruhan diikuti dengan tingginya nilai TSS dan berbanding terbalik dengan kecerahan perairan. Keruhnya suatu perairan disebabkan oleh banyaknya partikel-partikel yang terlarut didalam kolom perairan sehingga menyebabkan terhambatnya penetrasi cahaya matahari yang masuk ke kolom perairan. Hal ini akan membuat terumbu karang sulit untuk melakuakan proses fotosintesis (Tanto dan Kusumah, 2016).

Parameter kualitas perairan yang berkorelasi positif terhadap terumbu karang diantaranya suhu, DO, pH, salinitas, kecerahan, kedalaman dan kecepatan arus. Artinya meningkatnya nilai parameter tersebut diikuti oleh meningkatnya persentase terumbu karang hidup. Akan tetapi ada batas ambang yang dapat ditoleransi oleh terumbu karang. Selain itu parameter kualitas perairan yang berkorelasi negatif terhadap terumbu karang diantaranya fosfat, substrat, kekeruhan, TSS, BOD5, dan nitrat. Hal ini berarti kenaikan nilai dari parameter ini akan menurunkan persentase tutupan terumbu karang hidup di perairan Desa Pemuteran.

\section{Simpulan dan Saran}

Dari penelitian yang sudah dilakukan dapat disimpulkan bahwa kualitas perairan Desa Pemuteran secara umum masih dalam kondisi baik berdasarkan Keputusan Menteri Lingkungan Hidup Nomor 51 (2004) tentang Baku Mutu Air untuk Biota Laut. Akan tetapi beberapa parameter kualitas perairan tidak sesuai bagi pertumbuhan terumbu karang. Parameter tersebut adalah suhu, salinitas, nitrat dan fosfat.

Persentase tutupan terumbu karang pada titik 1 sebesar 50,67\%, titik 2 sebesar $65 \%$, titik 3 sebesar $35 \%$, titik 4 sebesar $85,33 \%$ dan titik 5 sebesar 16,67\%. Sedangkan titik 6 - 10 tidak terdapat terumbu karang.

Berdasarkan analisis komponen utama parameter kualitas perairan yang lebih mempengaruhi terumbu karang di Desa Pemuteran yaitu kekeruhan dan substrat.

Berdasarkan hasil analisis korelasi menunjukkan bahwa suhu perairan dan nitrat berkorelasi sangat lemah terhadap terumbu karang. Parameter kualitas perairan yang berkorelasi cukup terhadap terumbu karang yaitu pH, DO, BOD, dan fosfat. Korelasi kuat terjadi antara parameter kualitas air seperti salinitas, kecepatan arus, dan TSS dengan terumbu karang. Sedangkan yang memiliki korelasi sangat kuat terhadap terumbu karang di perairan Desa 
Pemuteran adalah kedalaman, kecerahan, kekeruhan dan substrat.

Saran yang dapat diberikan adalah perlu adanya penelitian lanjutan mengenai perbandingan hubungan kualitas perairan dengan terumbu karang pada musim hujan dan musim kemarau. Perlu adanya pemantauan kualitas air secara berkala untuk menghindari terjadinya pencemaran sehingga dapat dilakukan upaya pencegahan sebelumnya.

\section{Ucapan terimakasih}

Terimakasih kepada Dinas Perikanan dan Kelautan Kabupaten Buleleng, Yayasan Reef Check Indonesia, Coral Aliance dan Kelompok Masyarakat Karang Lestari.

\section{Daftar Pustaka}

Ardiansyah, E. F., Hartoni, \& Litasari, L. (2013). Kondisi tutupan terumbu karang keras dan karang lunak di Pulau Pramuka Kabupaten Administratif Kepulauan Seribu DKI Jakarta. Maspari Journal, 5(2), 111-118.

Arifin, F., Dirgayusa, I. G. N. P., \& Faiqoh, E. (2017). Struktutr Komunitas Ikan dan Tutupan Karang di Area Biorock Desa Pemuteran, Buleleng, Bali. Journal of Marine and Aquatic Sciences, 3(1), 59-69.

As-syakur, A. R., \& Wiyanto, D. B. (2016). Studi kondisi hidrologis sebagai lokasi penempatan terumbu buatan di peraitan Tanjung Benoa Bali. Jurnal Kelautan, 9(1), 85-92.

BLH Provinsi Bali. (2010). Status Lingkungan Hidup Daerah Provinsi Bali 2010. Denpasar, Indonesia. Badan Lingkungan Hidup (BLH) Provinsi Bali.

BPS Kabupaten Buleleng. (2015). Kecamatan Gerokgak Dalam Angka 2015. Buleleng, Indonesia: Badan Pusat Statistik Kabupaten Buleleng.

DeCarlo, T. M., Cohen, A. L., Wong, G. T., Davis, K. A., Lohmann, P., \& Soong, K. (2017). Mass coral mortality under local amplification of $2^{\circ} \mathrm{C}$ ocean warming. Scientific Reports, 7, 44586.

Dunning, K. H. (2015). Ecosystem services and community based coral reef management institutions in post blast-fishing Indonesia. Ecosystem Services, 16, 319-332.

Eghbert, E. A., Johan, O., Menkes, C. E., Niño, F., Birol, F., Ouillon, S., \& Andréfouët, S. (2017). Coral mortality induced by the 2015-2016 El-Niño in Indonesia: the effect of rapid sea level fall. Biogeosciences, 14(4), 817.

Hamzah, F., Basit, A., \& Triyulianti, I. (2015). Pola sebaran vertikal nutrien pada musim peralihan di
Teluk Weda, Maluku Utara. Jurnal Ilmu dan Teknologi Kelautan Tropis,7(2), 415-431.

Insafitri. (2010). Prosentase penutupan karang di Pulau Kangean-Sumenep. Jurnal Kelautan, 3(2), 112-116.

MNLH. (2004). Keputusan Menteri Negara Lingkungan Hidup Nomor 51 Tahun 2004 tentang Kriteria Baku Mutu Air untuk Biota Laut. Jakarta-Indonesia: Menteri Negara Lingkungan Hidup.

Mustika, P. L., Ratha, I. M. J., \& Purwanto, S. (2012). Kajian Cepat Kondisi Kelautan Provinsi Bali 2011. $\left(2^{\text {th }}\right.$ ed). RAP Bulletin of Biological Assessment 64 . Denpasar, Indonesia: Dinas Perikanan dan Kelautan Provinsi Bali, Balai Riset dan Observasi Kelautan Bali, Universitas Warmadewa, Conservation International Indonesia.

Putra, M. I. H., Indrayanti, E., \& Zainuri, M. (2015). Variabilitas suhu dan kecepatan arus terhadap keberadaan ikan matahari (Mola ramsayi) di perairan Kepulauan Nusa Penida. Jurnal Oseanografi, 4(3), 545555.

Ramadhani, R. A., Damar, A., Madduppa, H. (2015). Pengelolaan ekosistem terumbu karang di Kecamatan Siatan Tengah Kabupaten Kepulauan Anambas. Jurnal Ilmu dan Teknologi Kelautan Tropis, 7(1), 173-189.

Rini, D. A. S., Pratikto, W. A., \& Sambodo, K. (2015). Identifikasi potensi kawasan sumberdaya Pulau Kangean Kabupaten Sumenep Madura sebagai kawasan wisata bahari. Jurnal Kelautan, 8(2), 60-70.

Rokhim, K., Arisandi, A., \& Abida, I. W. (2009). Analisa kelimpahan fitoplankton dan ketersediaan nutrien (NO3 dan PO4) di perairan Kecamatan Kwanyar Kabupaten Bangkalan. Jurnal Kelautan, 2(2), 45-55.

Salim, D. (2012). Pengelolaan Ekosistem Terumbu Karang Akibat Pemutihan dan Rusak. Jurnal Kelautan, 5(2), 142-155.

Siringoringo, R. M., \& Hadi, T. A. (2013). Kondisi dan distribusi karang batu (Scleractinia corals) di perairan Bangka. Jurnal Ilmu dan Teknologi Kelautan Tropis, 5(2), 273-285.

Tamam, B., Arisandi, A., \& Saleh, M. (2013). Inventarisasi terumbu karang di Pulau Mamburit Kepulauan Kangean Kabupaten Sumenep. Jurnal Kelautan, 6(2), 120-127.

Tanto, T. A., \& Kusumah, G. (2016). Kualitas peraitan Teluk Bungus berdasarkan baku mutu air laut pada musim berbeda. Maspari Journal, 8(2), 135-146.

Twinandia, D., Mubarak, A. S., \& Mukti, A. T. (2011). Pengaruh luas penutupan terumbu karang pad lokasi biorovk dan reef seen terhadap keragaman spesies ikan di wilayah perairan Pemuteran Bali. Jurnal Ilmiah Perikanan dan Kelautan, 3(2), 151-155.

Ulqodry, T. Z., Yulisman, Syahdan, M., \& Santoso. (2010). Karakteristik dan sebaran nitrat, fosfat dan oksigen terlarut di perairan Karimunjawa, Jawa Tengah. Jurnal Penelitian Sains, 13(1), 34-43. 
Yolanda, D. S., Muhsoni, F. F., \& Siswanto, A. D. (2016). Distribusi nitrat, oksigen terlarut, dan suhu di perairan Socah-Kamal Kabupaten Bangkalan. Jurnal Kelautan, 9(2), 93-98.

(C) 2017 by the authors; licensee Udayana University, Indonesia. This article is an open access article distributed under the terms and conditions of the Creative Commons Attribution license (http://creativecommons.org/licenses/by/3.0/). 